\title{
KIRJOITUS
}

KAISA PUUSTINEN

\section{Tukea perheille ja nuorille poikkeusoloissa selviytymiseen Joensuussa}

\footnotetext{
Toensuun seurakuntayhtymässä toteutettiin touko-joulukuussa 2020 ESR-rahoitteinen hanke 'tukea nuorille ja perheille Joensuun alueella covid-19 poikkeusoloista selviytymiseksi'. Hankkeessa pyrittiin tavoittamaan perheitä ja nuoria, joiden toimeentuloon ja elämän mielekkyyteen korona oli alentavasti vaikuttanut. Hankkeessa työskenteli kaksi yhtymän työntekijää, diakoni Katja Nuuhkarinen sekä pastori Kaisa Puustinen.

Hankkeen tavoitteena oli auttaa koronan vuoksi hankalaan asemaan joutuneita perheitä. Asiakashankinnassa käytettiin hyödyksi yhtymän diakonija lapsityöntekijöidenverkostoa, sosiaalihuollon kontakteja sekä toisen asteen oppilaitosten opinto-ohjaajia. Hankkeen tarkoituksena oli mahdollistaa asiakasperheille jotain sellaista, mihin heillä ei taloudellisista tai terveydellisistä syistä johtuen ollut mahdollisuuksia, ja joiden elämänlaatua poikkeusolot olivat entisestään heikentäneet.

Kaiken kaikkiaan hankkeessa oltiin kontaktissa 48 perheeseen, joissa oli yhteensä 67 aikuista sekä 120 lasta ja nuorta. Asiakasperheille lähetettiin asiakassuhteen alkupuolella Google Formsilla toteutettu kysely, jossa kartoitettiin perheiden taustaa ja hyvinvointia. Kyselyyn saatiin 29 vastausta, ja kaikki vastanneet antoivat luvan käyttää vastauksiaan myös tutkimuskäytössä.
} 


\section{Asiakkaat}

Kyselyssä kartoitettiin perheiden kokonpanoja, lasten ja aikuisten määrää, lasten ikiä sekä sitä, onko lapsella/lapsilla erityisen tuen tarpeita.

Kyselyn yhteenvedosta käy ilmi, että yksinhuoltajien määrä on selkeästi korostunut, sillä lähes kaksi kolmannesta vastanneista perheistä oli yksinhuoltajaperheitä. Näissä perheissä huoltajalla ei ollut uutta kumppania. Vastanneista hieman alle kolmannes eli ydinperheessä, ja noin joka kymmenes uusioperheenä.

Lasten lukumäärä perheissä oli vaihteleva. Kaikkiaan vastauksen antaneissa perheissä oli 63 lasta. Perheiden lapsimäärät jakautuivat melko tasaisesti kolmeen kolmannekseen: yhdessä kolmanneksessa lapsia oli yksi, toisessa lapsia oli kaksi ja kolmannessa vastauksen antaneessa perheessä lapsia oli kolme tai enemmän.

Lasten ikäjakauman mukaan avustettavissa perheissä oli runsaasti kouluikäisiä lapsia ja nuoria; pääosin alakouluikäisiä. Toisiksi eniten perheissä oli yläkouluikäisiä ja toista astetta käyviä nuoria. Alle kouluikäisiä lapsia oli noin joka kolmannessa apua hakeneessa perheessä. Lisäksi hieman yli puolet vastanneista ilmoitti perheessään olevan erityistä tukea tarvitsevia lapsia.

\section{Perheiden lähtötilanne ja tuen tarve}

Tuen tarvetta perheissä kartoitettiin sekä monivalintakysymyksillä että avoimilla kysymyksillä. Ensimmäinen monivalintakysymyssarja käsitteli asioita, jotka olivat olleet hyvin ennen korona-aikaa. Kysymyslistan tarkoituksena oli muodostaa arvio perheen normaalitilanteesta ennen poikkeusoloja, ja toimia taustatietona toiselle kysymyssarjalle, jossa tiedusteltiin koronan vuoksi kestämättömiksi muuttuneita asioita. Kysymyssarjoilla koottiin tietoa hankkeen kohdennuksen tarpeisiin, mutta pyrittiin myös auttamaan vastaajia huomioimaan hyvinvointiaan laajemmin. Kyselyt toimivat hankkeessa keskustelujen pohjana.

Vastaajista 20 kertoi säännöllisen päivärytmin olleen hyvä, 18 vastasi ateriarytmin toimineen, 18 kertoi kodin olleen viihtyisä ja 17 saaneensa riittävästi unta. 17 kertoi aikuisten ja lasten välisten suhteiden olleen toimivat ennen poikkeusoloja. 
1. Mitkä asiat olivat hyvin ennen koronapandemiaa?

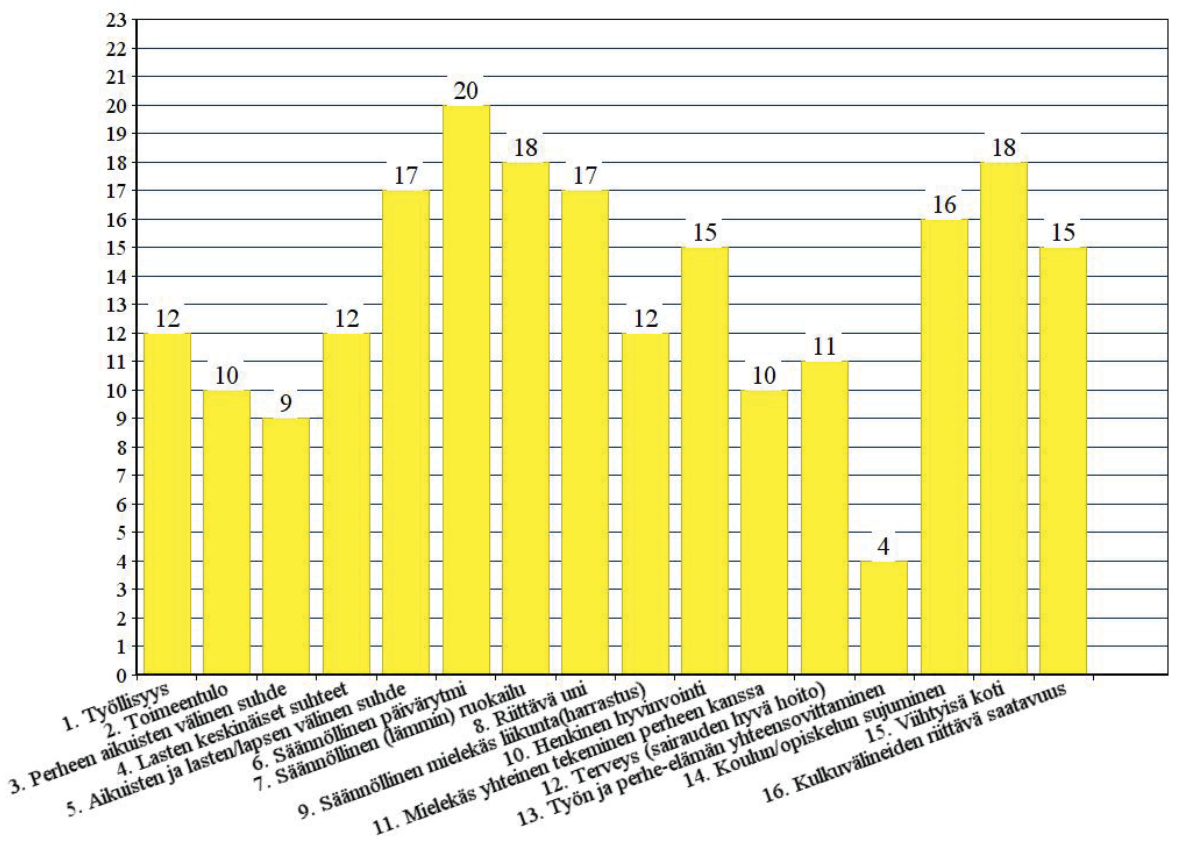

Kuvio 1 Positiivinen lähtötilanne

Useilla hankkeeseen osallistuneella perheillä oli elämässään haasteita ennen poikkeusoloja. Vastaajista neljä kertoi työn/opiskelun ja kotielämän yhteensovittamisen olleen toimivaa, yhdeksän kertoi perheen aikuisten suhteen olleen hyvä ja 10, että perheen toimeentulo oli ollut riittävää. Vastaajista 10 kertoi perheellä olleen myös mielekkäitä yhteisiä harrastuksia ennen poikkeusoloja. Vastaajista 12 kertoi perheen työllisyystilanteen olleen hyvä. Merkillepantavaa on, että toimeentulo koettiin riittäväksi vain kymmenessä perheessä ennen korona-aikaa. 


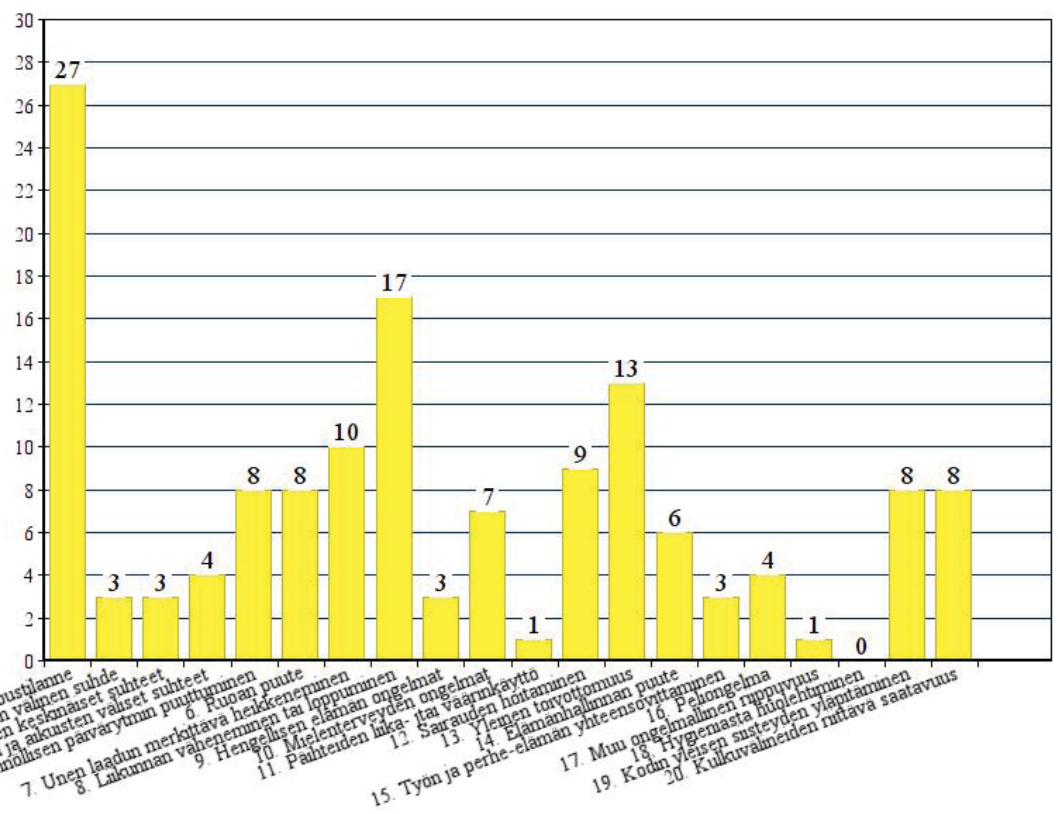

Kuvio 2 Tuen tarpeen lähtötilanne

Toinen monivalintakysymyssarja käsitteli asioita, jotka olivat muuttuneet kestämättömiksi koronasta johtuen. Hankkeen tarkoituksena oli kartoittaa ja tarjota tukea mahdollisimman laaja-alaisesti asiakasperheille. Monivalintakysymyssarja koettiin käytännölliseksi lähestymistavaksi kartoituksen apuvälineenä, sillä se mahdollisti vastaajille ohjatun tilaisuuden tarkastella omaa hyvinvointiaan laaja-alaisesti.

Lähes kaikki vastaajat ilmoittivat taloustilanteensa heikentyneen koronan vuoksi. Kysymyksen asettelussa käytettiin sanaa 'kestämätön'. Tällä sanavalinnalla ohjattiin vastaajia määrittelemään tilanteensa vakavuutta kokemuspohjaisesti. Taloudellisen tilanteen huononeminen koronan vuoksi oli merkittävä. Toisiksi suurimpana ongelmana vastaajat kertoivat kokevansa liikunnan vähentyneen tai loppuneen. 


\section{Apua taloudellisessa hädässä}

Asiakkaiden tuen tarve oli ensisijaisesti taloudellista. Hanketta ei lähtökohtaisesti ollut tarkoitettu vastaamaan perustarpeissa esiin tulleisiin puutoksiin, vaan hankkeen tarkoituksena oli mahdollistaa muita elämänlaatua parantavia tekijöitä.

Hanke kartoitti asiakkaiden tarpeet yksilöllisesti. Ensisijaisena tähtäyspisteenä oli elämänlaadun parantaminen ja poikkeusoloissa selviäminen. Näkökulma johti varsin laajaan kattaukseen avustustoimia, joten hankkeesta hankittiin muun muassa:

- Kuivausrumpu perheeseen, joka riskiryhmään kuuluvana toteutti omaehtoista karanteenia, ja pienessä asunnossa kuivumaan levitetyt pyykit hankaloittivat hengittämistä sekä olivat jatkuvasti tiellä perheen sulkeuduttua sisätiloihin keväällä 2020.

- Sänky teini-ikäiselle, jonka elämänpiiri kutistui kaupungista omaan huoneeseen. Aiemmin hän nukkui patjalla lattialla.

- Erilaisia kodintarvikkeita pesukoneista kalusteisiin kodin viihtyvyyden parantamiseksi ja kotona olemisen helpottamiseksi.

- Lahjakortteja OMT-fysioterapiaan tapauksissa, joissa fyysinen kipu tai vaiva hankaloitti merkittävästi arjen sujumista tai esti mahdollisen työn vastaanottamisen.

- Polkupyöriä, koska riskiryhmäläiset kokivat julkisen liikenteen olevan terveysriski.

- Muutaman päivän mökkilomia ja pieniä irtiottoja arjesta. Hanke mahdollisti kulkuvälineen ja yöpymisen sekä ruokailemisen. Tarkoituksena oli, ettei irtiotto heikentäisi perheiden normaalia taloustilannetta.

- Lapsenvahteja yksinhuoltajille opintojen suorittamiseksi ja oman ajan saamiseksi. Rekrytoinnissa käytettiin muun muassa Itä-Suomen yliopiston erityisopettajaksi opiskelevien Yammer-ryhmää. Hanke maksoi opiskelijoille lastenhoidosta palkkion. Lisäksi he saivat suoritusmerkinnän opintorekisteriinsä yliopistolta.

- Lapsille ja nuorille kuulokkeita, tabletteja ja harrastusvälineitä, kuten virveleitä ja suksia sekä kausivaatteita ja -kenkiä erityisesti talveksi.

Joissain perheissä Kelan laskelmien mukaisen perustoimeentulon turvaaminen ja jo saadut diakonia-avustukset eivät riittäneet kattamaan perheen 
välttämättömiä kuukausittaisia menoja. Näissä tapauksissa hanke etsi maksukumppanin joko asiakkaan oman seurakunnan diakoniatyöstä tai sosiaalihuollosta ja mahdollisti näin esimerkiksi sähkönjakelun jatkumisen, sillä hankkeesta arvioitiin sähkön olevan oleellinen tekijä elämänlaadun ylläpitämisessä varsinkin talvella. Yhteismaksusopimuksia tehtiin myös lasten harrastuskulujen kattamiseksi.

Hankkeen tarkoituksena oli helpottaa asiakkaiden stressiä ja edesauttaa toimintakyvyn säilymistä poikkeusoloissa. Tähän tähtäsivät myös yksinhuoltajille mahdollistettu lastenhoitoapu sekä lahjakortit fysioterapiaan. Vanhempien oman ajan tarve korostui poikkeusoloissa erityisesti perheissä, joissa oli yksi tai useampi erityistä tukea tarvitseva lapsi.

\section{Elämän mielekkyyttä etsimässä}

Hankkeen asiakkaista useilla oli työn vastaanottamiseen tai tekemiseen liittyviä haasteita. Työn saamista hankaloittivat muun muassa koulutuksen puute, fyysinen vaiva sekä sairauslomaan tai -eläkkeeseen johtanut pitkäkestoinen henkinen pahoinvointi. Lisäksi useiden asiakkaiden työtilanne oli heikentynyt tai työsopimukset oli irtisanottu poikkeusolojen alettua. Hanke edesauttoi työllistymistä muun muassa järjestämällä kontakteja asiakkaiden ja työnvälittäjien välille.

Työn puute tai kykenemättömyys työn tekemiseen aiheutti stressiä ja hankaloitti arjen sujumista henkisen hyvinvoinnin vähentyessä. Kyselyyn vastanneista 13/29 ilmoitti yleisen toivottomuuden kasvaneen kestämättömäksi. Unenlaadun heikkenemisestä mainitsi 10 ja sairauden hoitamisen hankaloitumisesta mainitsi yhdeksän vastaajaa. Lisäksi mielenterveyden heikkenemisestä mainitsi seitsemän vastaajaa.

Kyselyn perusteella taloustilanteen jälkeen merkittävin heikkeneminen oli tapahtunut säännöllisessä liikkumisessa ja harrastuksissa. Tämä tekijä voi olla osatekijä yleisen pahoinvoinnin lisääntymisessä, mutta myös seuraus heikentyneestä hyvinvoinnista. Yleisen toivottomuuden ja stressin lisääntyessä ja rajoitusten kiristyessä omasta fyysisestä kunnosta huolehtiminen on monin paikoin käynyt hankalaksi. Lisäksi ammatillisten hoitavien tahojen henkisen tuen toimintamuodot ovat muuttuneet: joko käyntejä ja tapaamisia on harvemmin tai tapaamiset on siirretty verkkotapaamisiksi. Asiakkaat kuvailivat avunsaannin muutosten aiheuttaneen ylimääräistä pahoinvointia. Kaikkiaan 
pahoinvoinnin vyyhti asiakasperheissä oli monitahoinen. Hanke pyrki vastaamaan henkisen pahoinvoinnin ongelmiin tarjoamalla keskusteluapua sekä lisäkontakteja muihin auttaviin tahoihin.

\section{Lopuksi}

Kullekin asiakkaalle lähetettiin avustusjakson jälkeen yhteistyöpalautekysely hankkeeseen osallistumisesta. Palautteen perusteella hankeen tavoitteet asiakkaiden elämänlaadun parantumisesta täyttyivät.

Tämän hankkeen kesto oli varsin lyhyt. Toimintaa ja tuen muotoja pyrittiin kuitenkin suuntaamaan myös pidemmän aikavälin ratkaisuiksi. Asiakkaiden aikahorisontti osoittautui lyhyeksi, eikä pitkäkestoisten ratkaisujen miettiminen tai luominen ollut yksinkertaista. Monen oli hankala hahmottaa talouttaan kahta viikkoa pidemmälle. Taloudellisen avuntarpeen lisäksi hankkeen asiakaskunnassa havaittiin siis huomattava tarve elämänhallinnan taitojen tukemiseen. 